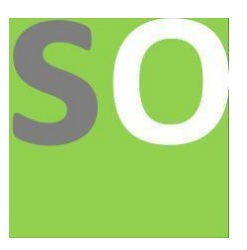

Article title: Evaluation Of The Hura Crepitans Seed Oil On Lipidomics Of Some Tissues In Albino Rats Authors: Oluwakemi Inegbenose[1], Regina Ugbaja[2], Oladipo Ademuyiwa[3], Catherine Eromosele[4]

Affiliations: Biochemistry Department, Federal University of Agriculture, Abeokuta, Ogun State. Nigeria[1], Chemistry Department, Federal University of Agriculture, Abeokuta, Ogun State. Nigeria[2]

Orcid ids: 0000-0002-7205-4839[1]

Contact e-mail: inegbenoseoluwakemi@gmail.com

License information: This work has been published open access under Creative Commons Attribution License http://creativecommons.org/licenses/by/4.0/, which permits unrestricted use, distribution, and reproduction in any medium, provided the original work is properly cited. Conditions, terms of use and publishing policy can be found at https://www.scienceopen.com/.

Preprint statement: This article is a preprint and has not been peer-reviewed, under consideration and submitted to ScienceOpen Preprints for open peer review.

DOI: 10.14293/S2199-1006.1.SOR-.PPCHNOV.v1

Preprint first posted online: 07 January 2021

Keywords: Hura crepitans, seed oil, Edibility, Lipids, Albino Rats, HCSO 


\title{
EVALUATION OF HURA CREPITANS SEED OIL ON LIPIDOMICS OF SOME TISSUES IN ALBINO RATS
}

\author{
UGBAJA, R.N ${ }^{1}$; INEGBENOSE, O.E ${ }^{1}$; ADEMUYIWA, O. ${ }^{1}$; EROMOSELE, C.Oª \\ 1. Department of Biochemistry, College of Biological Sciences, Federal University of \\ Agriculture, Abeokuta, Abeokuta Ogun State, Nigeria
}

2. Department of Chemistry, College of Biological Sciences, Federal University of Agriculture, Abeokuta.

\begin{abstract}
Nuts and seeds are good sources of oil. Most of these oil are edible and are of industrial use. In term of edibility, some seed oils are hyperlipidemic, while some are hypolipidemic. The Hura crepitans (sandbox tree) is one of the plants that bear seeds however, the seeds has not been fully utilized. This study investigated the effects of Hura crepitans seed oil on lipidomics of some tissues (blood, liver, heart, kidney and brain) in albino rats. The Hura crepitans seed oil (HCSO) was extracted with Soxhlet extractor using petroleum ether as solvent. Twenty-four male albino rats allocated to four groups of 6 rats each were used. Groups 1-3 were fed diet containing $5 \%, 10$ $\%$ and $15 \%$ HCSO respectively while group 4 was fed diet containing $15 \%$ groundnut oil (GO) (control) for 8 weeks. Whole blood was collected and the tissues (liver, heart, brain and kidney) were harvested. Cholesterol, triacylglycerol and phospholipid levels were determined in plasma, $\mathrm{RBC}$ and tissues of the rats spectrophotometrically. Hepatic HMG-CoA reductase activity was indirectly determined using spectrophotometric method. One-way analysis of variance (ANOVA) and Tukey's test were used to analyse the results. The lipids analyses showed that HDL and VLDL cholesterol levels decreased significant $(\mathrm{p}<0.05)$ in the $5 \%$ and $15 \%$ HCSO groups and in plasma, liver and kidney of $10 \%$ HCSO group. Also a significantly $(\mathrm{p}<0.05)$ increase was observed in RBC cholesterol level in $5 \%$ and $15 \%$ HCSO groups while cardiac cholesterol level increased significantly in $10 \% \mathrm{HCSO}$ group. Triacylglycerol level increased significantly in plasma, VLDL and liver (5 \% and 10\% HCSO group), kidney and brain (5\% HCSO group), RBC and heart (15\% HCSO group) while a decrease ensued in HDL across the groups. The phospholipids level decreased significantly in all the organs except kidney of $15 \%$ HCSO group whereas an increase was observed in plasma, HDL, VLDL and RBC of all the groups. Hura crepitans seed oil is considerably hypolipidemic and could be edible and be beneficial to health especially at $10 \%$ composition.
\end{abstract}

Key word: Hura crepitans; seed oil; Edibility; Lipids. 


\section{INTRODUCTION}

Edible oils are gotten from seeds of some plants and animal fats. They are good sources of energy and nutrients serving as main constituent of various diets, especially essential fatty acids (Odeomelam, 2005; Akubugwo et al., 2008).

A good number of seed oils have been characterized. Attention has been shifted to evaluations of non-utilized oil seeds for possible edible use (Fowomola and Akindahunsi, 2007). The Hura crepitans (sandbox tree) is one of the seed-bearing plants that has not been fully evaluated, and there is a need to seek for more seed oils that will be beneficial to humans.

H. crepitans (Sandbox tree) is an evergreen tree of Euphobiaceae family that is freely available in Nigeria but has not been fully-utilized. It is recognized by many dark pointed spines that covers the bark and its large heart shaped leaves with prominent secondary veins.

The oil content for Hura crepitans ranges from $37.78 \%$ to $53.61 \%$ (w/w) (Oderinde et al., 2009; Okolie et al., 2012). Which make it suitable for industrial application (WHO, 1993). The crude protein ranges from 24.76 to 37.64 and crude fiber between 1.21 to $10.15 \pm 0.03$ (Oyeleke et al., 2012; Muhammed et al., 2013). Alabi et al. (2013) reported that the saponifiable matter of $H$. crepitans seed oil contains different fatty acids. Linoleic acid was found as major (36.6\%) followed by oleic acid (26.9\%) and palmitic acid (21.7\%). Moderate amount of stearic acid (9.7\%) and arachidic acid (2.5\%) was found. Myristic acid, palmitoleic acid, margaric acid, linolenic acid, behenic acid and lignoceric acid were found in very low quantity; $(0.2 \%)$, (0.6\%), $(0.3 \%),(0.8 \%),(0.3 \%)$ and $(0.5 \%)$ respectively. $35.2 \%$ and $64.9 \%$ were the total saturated and total unsaturated respectively.

Okolie et al. (2012) reported that the proportions of unsaturated and saturated fatty acids of $H$. crepitans seed oil was $66.483 \%$ and $8.994 \%$ respectively. $H$. crepitans seed oil is reported to have long shelf-life since the moisture content of $\mathrm{H}$. crepitans seed oil is $3.0 \%$ (Oderinde et al., 2009).

In Nigeria, the major sources of edible oil are groundnut also called peanut (Arachis hypogaea L.) and oil palm (Elaeis guineensis). These oils are used mainly as cooking oil and for the production of soap, margarine, and cosmetics (Ong et al., 1995). Vegetable oil had made an important contribution to the diet in many countries, serving as a good source of protein, lipid and fatty acids for human nutrition including the repair of worn out tissues, new cells formation as well as a useful source of energy (Gaydou et al., 1983; Grosso and Guzman, 1995; Grosso et al., 1997, 1999). Oil quality and its stability are therefore very important for the consumers and application industries (Jambunathan et al., 1993).

Findings have demonstrated that diets high in groundnut oil are as effective as olive oil in preventing heart disease and are heart healthy than very low fat diets (Ugbaja et al., 2015). Hence, this study sought to investigate and compare the effects of $H$. crepitans seed oil and groundnut oil as edible oil in diet on lipidomics of rat tissues. 
MATERIALS AND METHODS

Animals and Experimental Design: Twenty four male albino rats, were obtained from a reputable animal farm. They were maintained under standard conditions of humidity (40-60\%), temperature $\left(20-22{ }^{\circ} \mathrm{C}\right)$, and 12 hours light and 12 hours darkness cycle. They were acclimatized to housing conditions for two weeks prior to the commencement of the study. Their feeds as shown in table 1 were compounded with Hura crepitans seed oil and ground nut oil. The diets were fed to the rat for 8 weeks with fresh water ad libitum. The composition of feed is shown in Table 2.

\section{Blood collection and isolation of organs}

At the end of administration, the rats were sacrificed by anesthesia using diethyl ether. Blood was collected by cardiac puncture into Lithium-heparinized sample bottles. The whole blood samples was centrifuged immediately at 3000rpm for 15 minutes to separate plasma from red blood cells. The organs needed were harvested and kept in ice cold condition for further analysis, while the RBC were washed thrice with ice-cold physiological saline solution before using for analysis.

Table 1: Experimental design

\begin{tabular}{lcl}
\hline Group & No of Albino rats & Proportion of oil in compounded feed \\
\hline Group 1 (control) & 6 & Ground nut oil (GO) (15\%) \\
Group 2 & 6 & Hura crepitans seed oil (HCSO) $(15 \%)$ \\
Group 3 & 6 & HCSO $(10 \%)+$ GO $(5 \%)$ \\
Group 4 & 6 & HCSO $(5 \%)+$ GO $(10 \%)$ \\
\hline
\end{tabular}


Table 2: Composition of diet

\begin{tabular}{llccc}
\hline Composition & $\begin{array}{l}\text { Normal diet } \\
\mathrm{g} / 100 \mathrm{~g}\end{array}$ & $\begin{array}{c}15 \% \text { oil diet } \\
\mathrm{g} / 100 \mathrm{~g}\end{array}$ & $\begin{array}{c}10 \% \text { oil diet } \\
\mathrm{g} / 100 \mathrm{~g}\end{array}$ & $\begin{array}{c}5 \% \text { oil diet } \\
\mathrm{g} / 100 \mathrm{~g}\end{array}$ \\
\hline Maize & 40 & 40 & 40 & 40 \\
Flour binder & 10 & 10 & 10 & 10 \\
Soy Bean & 7 & 7 & 7 & 7 \\
Groundnut cake & 10 & 10 & 10 & 10 \\
Fish meal & 9 & 9 & 9 & 9 \\
Groundnut oil & 15 & 0 & 5 & 10 \\
Hura crepitans seed oil - & 5 & 15 & 10 & 5 \\
W/Offal & 1.4 & 5 & 5 & 5 \\
Bone & 2 & 1.4 & 1.4 & 1.4 \\
Premix (Broiler) & 0.1 & 2 & 2 & 2 \\
Lysine & 0.2 & 0.1 & 0.1 & 0.1 \\
Salt (NaCl) & 0.3 & 0.2 & 0.2 & 0.2 \\
Methionine & & 0.3 & 0.3 & 0.3 \\
& & & & \\
\hline
\end{tabular}

\section{Biochemical Analyses:}

Plasma concentrations of cholesterol and triacylglycerol were determined using the Cypress diagnostic kits. Plasma phospholipid was determined according to the method of Stewart (1979). HDL-cholesterol and triacylglycerol were determined in plasma with the same diagnostic kits after very low density lipoproteins and low density lipoproteins (VLDL-LDL) were precipitated using the method described by Gidez et al. (1982). HDL-phospholipids was determined according to the method of Stewart (1979).

RBC lipids were extracted using chloroform-isopropanol (7:11, v/v) described by Rose and Oklander (1965). For cholesterol determination, $0.1 \mathrm{ml}$ of the extract was evaporated to dryness at $60^{\circ} \mathrm{C}$ and $20 \mu \mathrm{l}$ of Triton X-100/chloroform mixture $(1: 1, \mathrm{v} / \mathrm{v})$ was added to the dried extract and evaporated again.

Cholesterol kit reagent $(1.0 \mathrm{ml})$ was added, mixed and incubated for 30 minutes before reading the absorbance in a spectrophotometer. Triacylglycerol concentration was determined by evaporating to dryness $0.1 \mathrm{ml}$ of the extract and adding $0.1 \mathrm{ml}$ of $97 \%$ ethanol to re-suspend the dried lipid. To 
this, $1 \mathrm{ml}$ of the triacylglycerol kit reagent was added, mixed and incubated for 30 minutes before the absorbance reading was taken.

RBC lipid extract $(0.1 \mathrm{ml})$ was pipetted into Eppendorf tube and evaporated to dryness over boiling water. To the extract was added $2 \mathrm{ml}$ chloroform and $2 \mathrm{ml}$ ammonium ferrothiocyanate and thoroughly mixed. The chloroform layer was carefully removed using Pasteur's pipette. The absorbance was read at $488 \mathrm{~nm}$ as described in determination of plasma phospholipids

For the organ lipid profiles, lipids were extracted from brain, heart, kidney and liver as described by Folch et al. (1957). Homogenate of the organs (10\%) was prepared in choloroform-methanol (2:1) mixture. The homogenates were then spun at $4000 \mathrm{rpm}$ for 10 minutes in a centrifuge and the supernatants containing the lipids were removed into clean Eppendorf tubes. After washing with $0.05 \mathrm{M} \mathrm{KCl}, 0.1 \mathrm{ml}$ each of the chloroform-methanol extract were used for the determination of cholesterol, triacylglycerol and phospholipids after being evaporated to dryness at $60^{\circ} \mathrm{C}$. The lipid profiles were determined in aliquots of the extracts as described for RBC above.

\section{Determination of HMG-CoA reductase activity}

The activity of 3-hydroxy-3-methyl-glutaryl-CoA (HMG CoA) reductase in the liver was determined indirectly using the method described by Rao and Ramakrishnan (1975) by estimating the ratio of HMG CoA: mevalonic acid as an index of enzymatic activity. Liver homogenate (10\% $\mathrm{w} / \mathrm{v})$ was prepared in saline arsenate solution $(\mathrm{lg} / \mathrm{L})$. Equal volumes of fresh $10 \%(\mathrm{w} / \mathrm{v})$ liver homogenate and dilute Perchloric acid $(50 \mathrm{ml} / \mathrm{L}$ ) were mixed, allowed to stand for 5 minutes and centrifuged at $2000 \mathrm{rpm}$ for 10 minutes. Then $1 \mathrm{ml}$ of the filtrate was treated with $0.5 \mathrm{ml}$ of freshly prepared hydroxylamine reagent (alkaline hydroxylamine in the case of HMG CoA and neutral hydroxylamine in the case of mevalonate), mixed and after 5 minutes, $1.5 \mathrm{ml}$ of ferric chloride reagent was added and shaken. The absorbance was read after 10 minutes at $540 \mathrm{~nm}$ versus a similarly treated saline/ arsenate blank.

\section{Statistical analysis:}

Results are expressed as mean \pm S.E.M. One way analysis of variance (ANOVA) followed by Tukey's Test was used to analyze the results with $\mathrm{p}<0.05$ considered significant.

\section{Results}

Table 3: Effects of H. crepitans seed oil and groundnut oil on plasma, HDL, LDL, VLDL and $\mathrm{RBC}$ cholesterol levels $(\mathrm{mg} / \mathrm{dL}$ 


\begin{tabular}{lllllll}
\hline & Baseline & $5 \%$ HCSO & $10 \%$ HCSO & $15 \%$ HCSO & $15 \%$ GO \\
\hline $\begin{array}{l}\text { Plasma } \\
\text { cholesterol }\end{array}$ & $103.84 \pm 0.69^{\mathrm{b}}$ & $110.42 \pm 2.75^{\mathrm{b}}$ & $84.62 \pm 3.84^{\mathrm{a}}$ & $111.25 \pm 1.26^{\mathrm{b}}$ & $110.29 \pm 1.60^{\mathrm{b}}$ \\
$\begin{array}{l}\text { HDL } \\
\text { cholesterol }\end{array}$ & $40.28 \pm 0.25^{\mathrm{a}}$ & $41.73 \pm 0.29^{\mathrm{a}}$ & $48.30 \pm 0.46^{\mathrm{b}}$ & $42.46 \pm 0.43^{\mathrm{a}}$ & $46.44 \pm 0.58^{\mathrm{b}}$ \\
$\begin{array}{l}\text { VLDL } \\
\text { cholesterol }\end{array}$ & $14.07 \pm 0.72^{\mathrm{b}}$ & $15.83 \pm 0.32^{\mathrm{b}}$ & $18.11 \pm 0.59^{\mathrm{c}}$ & $12.54 \pm 0.53^{\mathrm{a}}$ & $17.25 \pm 0.40^{\mathrm{c}}$ \\
$\begin{array}{l}\text { LDL } \\
\text { cholesterol }\end{array}$ & $38.32 \pm 0.67^{\mathrm{b}}$ & $37.23 \pm 2.50^{\mathrm{b}}$ & $21.12 \pm 3.49^{\mathrm{a}}$ & $36.95 \pm 2.16^{\mathrm{b}}$ & $36.97 \pm 1.94^{\mathrm{b}}$ \\
$\begin{array}{l}\text { RBC } \\
\text { cholesterol }\end{array}$ & $10.99 \pm 0.10^{\mathrm{a}}$ & $14.46 \pm 0.40^{\mathrm{b}}$ & $11.40 \pm 0.29^{\mathrm{a}}$ & $14.99 \pm 0.36^{\mathrm{b}}$ & $12.05 \pm 0.03^{\mathrm{a}}$ \\
\hline
\end{tabular}

Values are expressed as mean \pm SEM $(n=5)$.

Values with different superscripts in the same column are significantly different $(\mathrm{p}<0.05)$.

Table 4: Effects of $H$. crepitans sees oil and groundnut oil on plasma, HDL, LDL-VLDL and RBC triacylglycerol level $(\mathrm{mg} / \mathrm{dL})$

\begin{tabular}{llllll}
\hline & Baseline & $5 \% \mathrm{HCSO}$ & $10 \% \mathrm{HCSO}$ & $15 \% \mathrm{HCSO}$ & $15 \% \mathrm{GO}$ \\
\hline $\begin{array}{l}\text { Plasma } \\
\text { triacylglycerol }\end{array}$ & $76.41 \pm 1.62^{\mathrm{a}}$ & $110.44 \pm 1.13^{\mathrm{c}}$ & $99.60 \pm 4.09^{\mathrm{b}}$ & $115.16 \pm 1.6^{\mathrm{c}}$ & $87.76 \pm 1.19^{\mathrm{a}}$ \\
$\begin{array}{l}\text { HDL } \\
\text { triacylglycerol }\end{array}$ & $10.18 \pm 0.31^{\mathrm{a}}$ & $12.65 \pm 0.87^{\mathrm{a}}$ & $41.73 \pm 1.01^{\mathrm{b}}$ & $70.68 \pm 0.61^{\mathrm{d}}$ & $46.81 \pm 0.85^{\mathrm{c}}$ \\
$\begin{array}{l}\text { VLDL-LDL } \\
\text { triacylglycerol }\end{array}$ & $4.98 \pm 0.00^{\mathrm{b}}$ & $5.60 \pm 0.16^{\mathrm{b}}$ & $5.10 \pm 0.12^{\mathrm{b}}$ & $3.01 \pm 0.37^{\mathrm{a}}$ & $2.08 \pm 0.26^{\mathrm{a}}$ \\
$\begin{array}{l}\text { RBC } \\
\text { triacylglycerol }\end{array}$ & $9.32 \pm 0.44^{\mathrm{a}}$ & $13.02 \pm 0.15^{\mathrm{c}}$ & $11.81 \pm 0.16^{\mathrm{b}}$ & $16.43 \pm 0.26^{\mathrm{d}}$ & $13.50 \pm 0.05^{\mathrm{c}}$ \\
\hline
\end{tabular}

Values are expressed as mean \pm SEM $(n=5)$.

Values with different superscripts in the same column are significantly different $(\mathrm{p}<0.05$

Table 3 shows the cholesterol level in the plasma, HDL, LDL, VLDL-LDL and RBC of animals fed HCSO and GO compounded diets. The plasma cholesterol level of the $10 \% \mathrm{H}$. crepitans group was significantly reduced $(\mathrm{p}<0.05)$ compared to the levels obtained for the other 
HCSO groups and $15 \%$ groundnut oil. There was no significant $(\mathrm{p}>0.05)$ difference between 15 $\%$ groundnut oil and the other groups.

The HDL-cholesterol level of $10 \% \mathrm{H}$. crepitans and $15 \%$ groundnut oil groups were significantly $(\mathrm{p}<0.05)$ higher compared to the other groups. . The same was observed for VLDL-cholesterol level.

VLDL-cholesterol of $10 \% \mathrm{HCSO}$ and $15 \%$ groundnut oil groups were significantly $(\mathrm{p}<$ 0.05) higher compared to other groups, the least VLDL-cholesterol was observed in the $15 \%$ Hura crepitans groups. The group fed the $10 \%$ Hura crepitans diet had the least LDL-cholesterol and was significantly $(\mathrm{p}<0.05)$ different from the other groups. There was no significant difference between the $10 \%$ HCSO and $15 \%$ groundnut oil in red blood cells cholesterol. $5 \%$ and $15 \%$ HCSO had a significantly ( $\mathrm{p}<0.05$ ) higher red blood cells cholesterol compared to other groups

In table 4 , the effects of $H$. crepitans seed oil and groundnut on plasma, HDL and LDLVLDL triacylglycerol is presented. There was significant $(\mathrm{p}<0.05)$ increase in plasma triacylglycerol level of the $5 \%$ and $15 \%$ HCSO groups compared to $15 \%$ GO fed group. The 15 $\%$ HCSO group exhibited significantly $(\mathrm{p}<0.05)$ higher HDL triacylglycerol level compared to $15 \%$ groundnut.

There was no significant difference $(\mathrm{p}>0.05)$ between the $5 \% \mathrm{HCSO}$ and $10 \% \mathrm{HCSO}$ groups with higher VLDL-LDL triacylglycerol, also there was no significant difference between the $15 \%$ HCSO and $15 \%$ GO groups with lower VLDL-LDL triacylglycerol. On the other hand $15 \%$ HCSO group had significantly $(\mathrm{p}<0.05)$ higher RBC triacylglycerol level compared to $15 \%$ groundnut group while $10 \%$ HCSO had a significantly $(\mathrm{p}<0.05)$ lower RBC triacylglycerol level compared to $15 \%$ groundnut oil. There was no significant difference $(\mathrm{p}>0.05)$ between $5 \%$ HCSO and $15 \%$ HCSO groups.

Table 5: Effects of $H$. crepitans seed oil and groundnut oil on plasma, HDL, VLDL-LDL and RBC phospholipids (mg/dL)

\begin{tabular}{llllll}
\hline & Baseline & $5 \%$ HCSO & $10 \%$ HCSO & $15 \%$ HCSO & $15 \%$ GO \\
\hline $\begin{array}{l}\text { Plasma } \\
\text { phospholipid }\end{array}$ & $22.48 \pm 0.12^{\mathrm{a}}$ & $41.80+0.17^{\mathrm{c}}$ & $31.12 \pm 1.42^{\mathrm{b}}$ & $53.66 \pm 1.83^{\mathrm{d}}$ & $28.14 \pm 0.99^{\mathrm{b}}$ \\
$\begin{array}{l}\text { HDL } \\
\text { phospholipid }\end{array}$ & $22.30 \pm 0.00^{\mathrm{a}}$ & $29.48 \pm 0.35^{\mathrm{C}}$ & $34.78 \pm 0.28^{\mathrm{d}}$ & $34.83 \pm 0.57^{\mathrm{d}}$ & $26.12 \pm 0.53^{\mathrm{b}}$ \\
$\begin{array}{l}\text { VLDL-LDL } \\
\text { phospholipid }\end{array}$ & $22.18 \pm 0.00^{\mathrm{a}}$ & $21.94 \pm 0.09^{\mathrm{b}}$ & $23.60 \pm 0.19^{\mathrm{c}}$ & $20.81 \pm 0.12^{\mathrm{a}}$ & $20.44 \pm 0.07^{\mathrm{a}}$ \\
$\begin{array}{l}\text { RBC } \\
\text { phospholipid }\end{array}$ & $13.36 \pm 0.97^{\mathrm{b}}$ & $14.36 \pm 0.60^{\mathrm{b}}$ & $15.26 \pm 0.31^{\mathrm{b}}$ & $18.63 \pm 0.95^{\mathrm{c}}$ & $10.93 \pm 0.22^{\mathrm{a}}$ \\
\hline
\end{tabular}

Values are expressed as mean \pm SEM $(n=5)$.

Values with different superscripts in the same column are significantly different $(p<0.05)$. 
Table 5 shows there was no significant difference $(\mathrm{p}>0.05)$ in the plasma phospholipid level between the $10 \% \mathrm{HCSO}$ and $15 \%$ GO groups. $5 \% \mathrm{HCSO}$ and $15 \%$ HCSO had significantly ( $\mathrm{p}<0.05$ ) increased plasma phospholipid level compared to other groups. $10 \%$ and $15 \%$ HCSO exhibited a significantly $(\mathrm{p}<0.05)$ higher HDL phospholipid compared to other groups. On the other hand, $10 \%$ HCSO had the highest level of VLDL-LDL phospholipid and it was significant $(\mathrm{p}<0.05)$ difference compared to other groups. All the groups had significantly $(\mathrm{p}<0.05)$ higher RBC phospholipid level compared to $15 \%$ groundnut group.

Table 6: Effects of $H$. crepitans seed oil and groundnut oil on liver, heart, Kidney and brain cholesterol levels $(\mathrm{mg} / \mathrm{dL})$

\begin{tabular}{llllll}
\hline & Baseline & $5 \%$ HCSO & $10 \%$ HCSO & $15 \%$ HCSO & $15 \%$ GO \\
\hline $\begin{array}{l}\text { Liver } \\
\text { cholesterol }\end{array}$ & $2.22 \pm 0.389^{\mathrm{a}}$ & $15.81 \pm 0.29^{\mathrm{d}}$ & $8.20 \pm 0.29^{\mathrm{b}}$ & $12.44 \pm 0.34^{\mathrm{c}}$ & $12.79 \pm 0.38^{\mathrm{c}}$ \\
$\begin{array}{l}\text { Heart } \\
\text { cholesterol }\end{array}$ & $2.09 \pm 0.24^{\mathrm{b}}$ & $1.77 \pm 0.14^{\mathrm{a}}$ & $1.92 \pm 0.59^{\mathrm{b}}$ & $1.67 \pm 0.32^{\mathrm{a}}$ & $1.71 \pm 0.103^{\mathrm{a}}$ \\
$\begin{array}{l}\text { Kidney } \\
\text { cholesterol }\end{array}$ & $12.25 \pm 0.03^{\mathrm{a}}$ & $18.65 \pm 0.24^{\mathrm{c}}$ & $15.98 \pm 0.26^{\mathrm{b}}$ & $18.80 \pm 0.20^{\mathrm{c}}$ & $19.31 \pm 0.12^{\mathrm{c}}$ \\
$\begin{array}{l}\text { Brain } \\
\text { cholesterol }\end{array}$ & $9.88 \pm 0.03^{\mathrm{a}}$ & $17.81 \pm 0.05^{\mathrm{b}}$ & $17.69 \pm 0.18^{\mathrm{b}}$ & $18.34 \pm 0.09^{\mathrm{b}}$ & $18.35 \pm 0.17^{\mathrm{b}}$ \\
\hline
\end{tabular}

Values are expressed as mean \pm SEM $(n=5)$.

Values with different superscripts in the same column are significantly different $(\mathrm{p}<0.0$

Table 6 is the summary of the effect of $H$. crepitans seed oil and groundnut oil on liver, heart, Kidney and brain cholesterol levels. There was no significant difference $(\mathrm{p}>0.05)$ between the $15 \%$ HCSO and the $15 \%$ GO group hepatic cholesterol level. The hepatic cholesterol level of $5 \%$ HCSO was significantly ( $<<0.05$ ) high compared to $15 \%$ GO group, while the $10 \%$ HCSO had a lower hepatic cholesterol level compared to the $15 \%$ GO. In cardiac cholesterol, there was no significant difference in all the groups except for $10 \%$ HCSO with a significantly $(\mathrm{p}<0.05)$ increased cardiac cholesterol level compared to the $15 \%$ HCSO. No significant difference ( $\mathrm{p}>$ 0.05) in kidney cholesterol concentration in all the groups except for $10 \%$ HCSO group which was significantly $(\mathrm{p}<0.05)$ decreased. Also, no significant different in the concentration of brain cholesterol in all the groups as shown. 
Table 7: Effects of $H$. crepitans seed oil and groundnut oil on liver, heart, Kidney and brain triglycerol levels $(\mathrm{mg} / \mathrm{dL})$

\begin{tabular}{llllll}
\hline & Baseline & $5 \% \mathrm{HCSO}$ & $10 \% \mathrm{HCSO}$ & $15 \% \mathrm{HCSO}$ & $15 \% \mathrm{GO}$ \\
\hline $\begin{array}{l}\text { Liver } \\
\text { triacylglycerol }\end{array}$ & $4.64 \pm 0.11^{\mathrm{a}}$ & $8.58 \pm 0.22^{\mathrm{c}}$ & $8.56 \pm 0.04^{\mathrm{c}}$ & $4.62 \pm 0.10^{\mathrm{a}}$ & $6.82 \pm 0.17^{\mathrm{b}}$ \\
$\begin{array}{l}\text { Heart } \\
\text { triacylglycerol }\end{array}$ & $8.90 \pm 0.08^{\mathrm{a}}$ & $13.92 \pm 0.04^{\mathrm{b}}$ & $16.39 \pm 0.07^{\mathrm{c}}$ & $18.58 \pm 0.26^{\mathrm{d}}$ & $12.21 \pm 0.16^{\mathrm{b}}$ \\
$\begin{array}{l}\text { Kidney } \\
\text { triacylglycerol }\end{array}$ & $21.87 \pm 0.00^{\mathrm{d}}$ & $19.87 \pm 0.06^{\mathrm{c}}$ & $13.51 \pm 0.15^{\mathrm{a}}$ & $15.53 \pm 0.11^{\mathrm{b}}$ & $15.03 \pm 0.33^{\mathrm{b}}$ \\
$\begin{array}{l}\text { Brain } \\
\text { triacylglycerol }\end{array}$ & $12.42 \pm 0.06^{\mathrm{d}}$ & $10.91 \pm 0.18^{\mathrm{c}}$ & $8.23 \pm 0.05^{\mathrm{a}}$ & $9.89 \pm 0.05^{\mathrm{b}}$ & $9.96 \pm 0.04^{\mathrm{b}}$ \\
\hline
\end{tabular}

Table 7 present the summary of the effect of $H$. crepitans seed oil and groundnut oil on liver, heart, Kidney and brain triacylglycerol levels. There was a significant $(\mathrm{p}<0.05)$ increase in the hepatic triacylglycerol of the $5 \%$ and $10 \%$ HCSO groups compared to the $15 \%$ groundnut oil group, while the $15 \%$ HCSO had a significantly $(\mathrm{p}<0.05)$ decreased hepatic triacylglycerol level compared to the $15 \%$ HCSO.

There was a significantly $(\mathrm{p}<0.05)$ increased cardiac triacylglycerol level in the $5 \%$ and $10 \%$ HCSO groups compared to $15 \%$ groundnut oil group.

$10 \%$ HCSO had a significantly $(\mathrm{p}<0$.05) reduced kidney triacylglycerol concentration compared to the $15 \%$ GO group while $5 \%$ HCSO had a significant $(\mathrm{p}<0.05)$ increased kidney level compared to the $15 \% \mathrm{GO}$.

On the other hand there was a significant $(\mathrm{p}<0.05)$ decreased in the $10 \%$ HCSO brain triacylglycerol level compared to the $15 \%$ groundnut 
Table 8: Effects of $H$. crepitans seed oil and groundnut oil on liver, heart, Kidney and brain phospholipid levels (mg/dL)

\begin{tabular}{llllll}
\hline & Baseline & $5 \%$ HCSO & $10 \%$ HCSO & $15 \%$ HCSO & $15 \%$ GO \\
\hline $\begin{array}{l}\text { Liver } \\
\text { phospholipid }\end{array}$ & $40.09 \pm 0.24^{\mathrm{d}}$ & $31.79 \pm 0.15^{\mathrm{c}}$ & $19.93 \pm 0.59^{\mathrm{b}}$ & $10.77 \pm 0.32^{\mathrm{a}}$ & $41.71 \pm 0.10^{\mathrm{d}}$ \\
$\begin{array}{l}\text { Heart } \\
\text { phospholipid }\end{array}$ & $9.44 \pm 0.02^{\mathrm{a}}$ & $13.67 \pm 0.31^{\mathrm{b}}$ & $12.77 \pm 0.07^{\mathrm{b}}$ & $15.17 \pm 0.47^{\mathrm{c}}$ & $14.53 \pm 0.04^{\mathrm{c}}$ \\
$\begin{array}{l}\text { Kidney } \\
\text { phospholipid }\end{array}$ & $13.45 \pm 0.03^{\mathrm{a}}$ & $20.20 \pm 0.85^{\mathrm{c}}$ & $17.29 \pm 0.19^{\mathrm{b}}$ & $24.71 \pm 0.23^{\mathrm{d}}$ & $21.22 \pm 0.16^{\mathrm{c}}$ \\
$\begin{array}{l}\text { Brain } \\
\text { phospholipid }\end{array}$ & $20.40 \pm 1.00^{\mathrm{a}}$ & $21.89 \pm 0.19^{\mathrm{a}}$ & $21.75 \pm 0.27^{\mathrm{a}}$ & $21.91 \pm 0.12^{\mathrm{a}}$ & $20.94 \pm 0.43^{\mathrm{a}}$ \\
\hline
\end{tabular}

Table 8 is the summary of the effect of $H$. crepitans seed oil and groundnut oil on liver, heart, Kidney and brain phospholipid levels. There were significant $(\mathrm{p}<0.05)$ decrease in hepatic phospholipid level in all the groups compared to the $15 \%$ GO.

There was no significant difference between the $15 \%$ HCSO and $15 \%$ GO group cardiac phospholipid level, meanwhile $5 \%$ and $10 \%$ HCSO had a significantly $(\mathrm{p}<0.05)$ decreased cardiac phospholipid level compared to the $15 \%$ GO.

$10 \%$ HCSO had a significantly reduced kidney phospholipid when compared to $15 \%$ GO group. There was no significant difference in the concentration of the brain phospholipid in all the groups.

Figure 1 explains the effects of the oil on the ratio of $\mathrm{HMG}-\mathrm{CoA} / \mathrm{Mevalonate}$. The ratio of HMG-CoA to Mevalonate in the liver is inversely proportional to the activity of the enzyme, HMG-CoA reductase. The activity of the enzyme in the $5 \% \mathrm{HCSO}, 15 \% \mathrm{HCSO}$ and $15 \%$ groundnut oil was significantly $(\mathrm{p}<0.05)$ higher than that of $10 \% \mathrm{HCSO}$. 


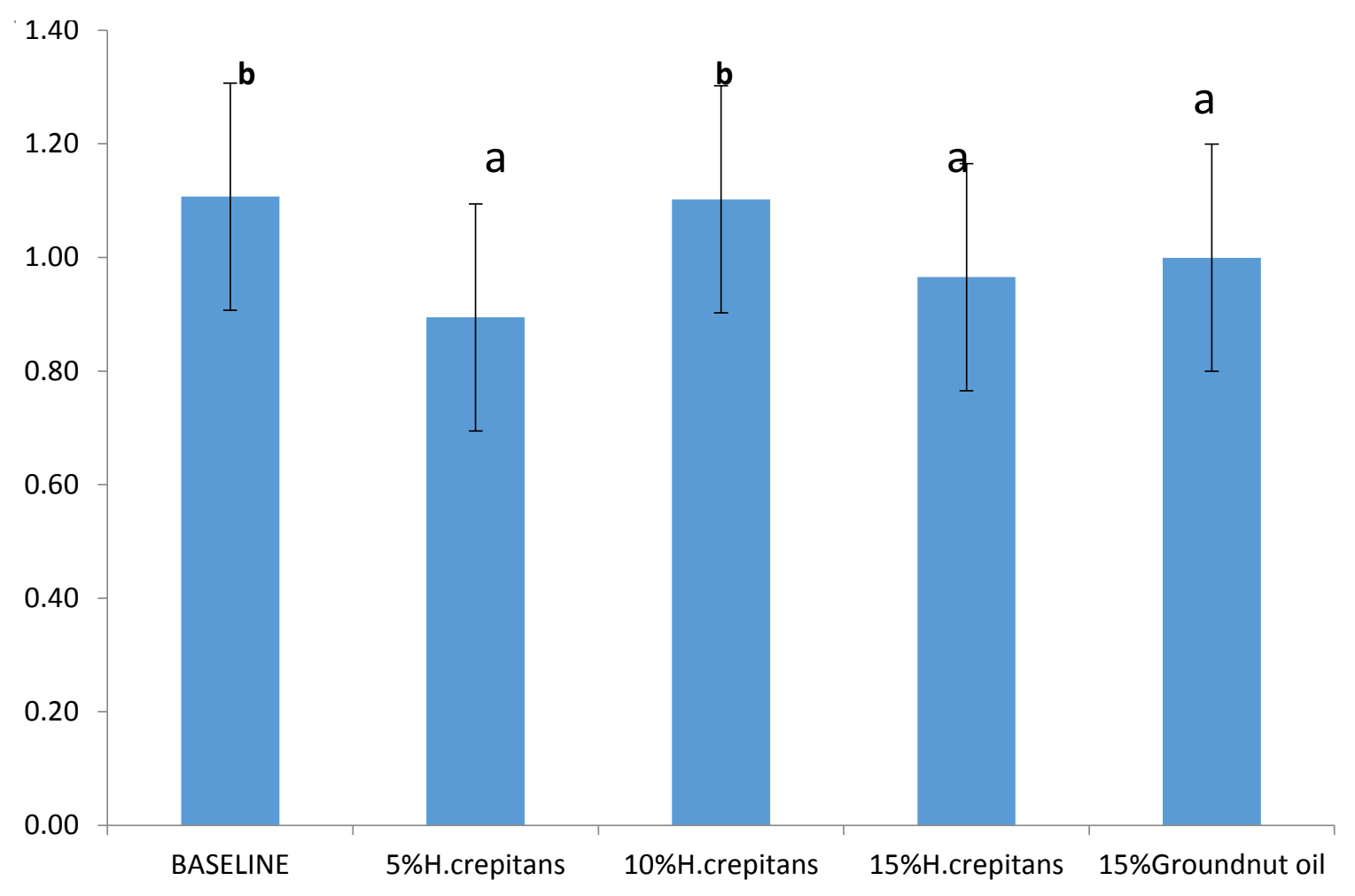

Group

Figure 1: Effects of $H$. crepitans seed oil and groundnut oil on ratio of HMG CoA to mevalonate in the liver

Bars are mean \pm SEM

Bars with different superscripts in the same column are significantly different $(\mathrm{p}<0.05)$. 


\section{DISCUSSION}

Lipids are considered one of the most elemental nutrients for humans. Lipid metabolism generates many bioactive lipid molecules, which are fundamental mediators of multiple signaling pathways and they are also indispensable compounds of cell membranes. Any kind of changes in lipid metabolism can result in modification of membrane composition and subsequently in changes in its permeability (Brenna, 2002; Burdge and Calder, 2005).

From the study, it is indicated that inclusion of both $H$. crepitans seed oil and groundnut oil at different percentage in the diet elicited different degree of tissue dyslipidemia. The dyslipidemia was shown by down-regulation and up- regulation of different lipids by the oils in various compartments.

It is a known fact that dietary oil intake plays a role in nutrition and health (Romon et al., 1995; Celebi and Utlu, 2006; Arterburn et al., 2008; Ighosotu and Tonukari, 2010; Ugbaja et al., 2015). They have an impact on total body fat composition and by extension metabolism of lipids (Oluba et al., 2011). In table 3, compared to the $15 \%$ GO (control) group, the dyslipidemia was characterized by hypocholesterolemia in $10 \%$ HCSO while there was no significant different between the control and the remaining group, whereas there was significant increase in the plasma triacylglycerol of both $15 \%$ and $10 \%$ HCSO group compared to 15\% GO. Ugbaja et al., 2015 reported that groundnut oils effected a decrease in the level of cholesterol and triacylglycerol in the plasma, which implies that groundnut oil is beneficial in nutrition and health. In this study, there is no significant different between the $15 \%$ GO and $15 \%$ HCSO plasma cholesterol this implies that HCSO could also be beneficial in nutrition and health in lowering plasma cholesterol and triacylglycerol, and could even bring the cholesterol to a lower level at $10 \% \mathrm{HCSO}$ concentration. Also, there was no significant different between the control and $10 \% \mathrm{HCSO}$ in the HDL cholesterol, whereas a decrease ensue in other groups compared to the $15 \%$ GO HDL-cho meanwhile in HDL triacylglycerol there was an increase in the $15 \%$ HCSO while other groups has a lower concentration compared to the $15 \% \mathrm{GO}$.

HDL is the smallest and densest of the lipoproteins, containing the highest proportion of protein to cholesterol. In a normal healthy individual, HDL carries about 20-30\% of total plasma cholesterol, whereas LDL (low density lipoprotein or bad cholesterol) carries about 70\%. HDL is important for the synthesis of steroid hormones but it is more famously known for its protective role against cardiovascular disease. Reverse cholesterol transport is the method by which HDL removes excess cholesterol from tissues and arteries, and returns it back to the liver for recycling and excretion, interrupting the process of atherosclerosis (narrowing of the arteries) at key stages. Its protective properties include anti -inflammatory activity, where it protects artery walls against LDL plus an anti- oxidative activity, which in combination, may directly slow atherosclerosis (Sanossian et al., 2007). 
From the result of this findings, the high HDL cholesterol observed in the $10 \% \mathrm{HCSO}$ could be as a result of the mixture of the two oil in the ratio 2:1 as the oils are rich in unsaturated fat, Groundnut oil as well as Hura crepitans oil are rich in unsaturated fatty acids. Groundnut oil is rich in oleic acid which increases HDL-cholesterol. (Ugbaja et al., 2015) On the other hand, saturated fat intake increases LDL-cholesterol and decreases HDL-cholesterol (Mensink and Katan, 1992). The $10 \%$ HCSO has the highest value of HDL-cholesterol and lowest value of LDLcholesterol when compared with the control. Hura crepitans oil could be effectively in lowering blood cholesterol, primarily LDL-cholesterol as it contains a good proportion of linoleic acid which favours the synthesis of LDL receptors on the liver and other tissue cells that will take up LDL and increase the process of reverse cholesterol transport especially from the heart to the liver for catabolism (Cedomila et al., 2001; Murray et al., 2003).

Cholesterol was significantly decreased in plasma by $10 \%$ HCSO, while cholesterol was significantly increase in HDL compartment of the $10 \%$ HCSO. This could be due to the combination of HCSO and GO in the ratio 2:1. Since groundnut oil is said to contain squalene (Azalia et al., 2018). Miettinen and Vanhanen (1994), reported that Chronic intake of squalene, mimicking a diet rich in squalene, led to increased cholesterol precursor sterols and raised cholesterol concentrations, but a smaller dose of squalene normalized the situation. The decrease cholesterol in plasma, liver and kidney in $10 \%$ HCSO could be attributed to the little amount of squalene in the diet. Little amount of squalene consumption has been found even to reduce serum cholesterol (Chan et al., 1996). The reduction in the level of cholesterol observed in this could be as a result of the long term intake of squalene though in a lesser amount in the case of $10 \%$ HCSO. Possible compensatory mechanisms to prevent the increase of serum cholesterol during a moderate long-term squalene consumption are reduced HMG-CoA reductase activity and increased fecal elimination of cholesterol as cholesterol itself and bile acids (Strandberg et al., 1990). There is, however, a conflict considering the lack of association between high squalene intake and coronary artery disease in Mediterranean populations consuming lots of olive oil (Keys et al., 1986). Daily doses that elevate serum cholesterol levels, i.e. $1 \mathrm{~g} /$ day, can be reached in individuals consuming large amounts (100 g/day) of olive oil. On the other hand, squalene has been reported to exhibit cellular radioprotective effects probably due to antioxidant properties (Storm et al., 1993). However, animal experiments have indicated that squalene feeding increases tissue squalene and cholesterol contents (Liu et al., 1975; Tilvis and Miettinen, 1983) reflecting stimulated cholesterol production from squalene. Labeled squalene administered to rats is converted to methyl sterols and rapidly to cholesterol mainly in the liver, with only trace amounts in the fat tissue (Miettinen and Vanhanen. 1994).

HDL enables lipids like cholesterol and triglycerides to be transported within the water-based bloodstream. In healthy individuals, about thirty percent of blood cholesterol is carried by HDL. Blood tests typically report HDL-C level, i.e. the amount of cholesterol contained in HDL particles. It is often contrasted with low density or LDL cholesterol. HDL particles are able to remove cholesterol from within artery atheroma and transport it back to the liver for excretion or 
re-utilization, which is the main reason why the cholesterol carried within HDL particles (HDLC) is sometimes called "good cholesterol" (despite the fact that it is exactly the same as the cholesterol in LDL particles). Those with higher levels of HDL-C seem to have fewer problems with cardiovascular diseases, while those with low HDL-C cholesterol levels (less than $40 \mathrm{mg} / \mathrm{dL}$ or about $1 \mathrm{mmol} / \mathrm{L}$ ) have increased rates for heart disease. (Ugbaja et al., 2015).

In this study, the $10 \%$ Hura crepitans seed oil proved to be quite effective in lowering the RBC cholesterol level and the increased triglycerides in the plasma and HDL fraction.

Phospholipids were increased in plasma, VLDL-LDL and HDL in all the group. These may be because, the diet generated a high level of circulating free fatty acids which favoured synthesis of triacylglycerols in the adipose tissue and major phospholipids in the blood probably by upregulating the enzyme involved in the synthesis of these lipids.

Also, it is known that diets rich in unsaturated fatty acids, mainly PUFAs, increase LDL receptor activity (Shepherd et al., 1980) increasing the uptake of cholesterol into tissues, and decrease very low density lipoprotein (VLDL) and LDL production rates (Turner et al., 1981: Cortese et $a l .$, 1983) followed by diminished circulating cholesterol concentration. The oils do not contain cholesterol, so the increase observed in the groundnut oil groups may be due to activation of HMGCoA reductase and the rate limiting enzyme in cholesterol synthesis (Sawada et al., 2005). The mechanism of the oil being able to do this is not yet understood, but it could be due to changes in the quantity of enzyme protein which is relatively slow compared to the rapid changes that occur from phosphorylation-dephosphorylation of the enzyme (Kennelly and Rodwell, 1985).

In figure 1, there was no significant different in all the groups except in $10 \%$ HCSO group when comparing it with the control, this shows that there was a decrease in the activity of the HMG CoA reductase enzyme in the $10 \%$ HCSO group.

In this study, it was discovered that the rats fed with Hura crepitans seed oil had a decreased cholesterol concentration compared to the groundnut oil group.

There was a decreased in the activity of the HMG CoA reductase enzyme in the Hura crepitans seed oil group compared to the groundnut oil group.

The result of this study implied that Hura crepitans seed oil was able to decrease the level of cholesterol and triacylglycerol in the RBC, kidney, liver and heart particularly at $10 \%$ composition. Therefore Hura crepitans seed oil is considerably hypolipidemic and edible especially at $10 \%$ composition. 


\section{REFERENCE}

Akubugwo, I. E., Chinyere, G. C. and Ugbogu, A. E. (2008). Comparative studies on oils from some common plant seeds in Nigeria. Pakistan Journal of Nutrition 7(4): 570-573.

Alabi, K. A., Lajide, L. and Owolabi, B. J. 2013. Analysis of Fatty Acid Composition of Thevetia peruviana and Hura crepitans Seed oils using GC-FID. Fountain Journal of Natural and Applied Sciences 2(2): $32-37$.

Arterburn, L. M., Oken, H. A., Bailey, H. E., Hamersley, J., Kuratko, C. N. and Hoffman, J. P. 2008. Algal-oil capsules and cooked salmon: Nutritionally equivalent sources of docosahexaenoic acid. Journal of American Diabetic Association 108: 1204 - 1209.

Azalia Lozalo-Grande M., Shela, G., Eduardo, E.R., Gloria. D. O. and Alma, L.M. 2018. Plant Sources, Extraction Methods, and Uses of Squalene. International Journal of Agronomy 18:29.

Brenna, J.T. 2002. Efficiency of conversion of a-linolenic acid to long chain n-3 fatty acids in man. Clinical Nutrition and metabolic care 5: 127-132.

Burdge, G.C. and Calder, P.C. 2005. Conversion of a-linolenic acid to longer-chain polyunsaturated fatty acids in human adults. Reproductive Nutrition Development, 45 (5): 581-597

Cedomila, M., Robert, D., Marin, T., Jasminks, G., Mira, C., Biserka, R. and Zlatko, C. 2001. Effect of olive oil and corn oil enriched diets on the tissue mineral content in mice. Biological Trace Element Research, 82: (1 - 3): $201-210$.

Celebi, S. and Utlu, N. 2006. Influence of animal and vegetable oil in layer diets on performance and serum lipid profile. International Journal of Poultry Science 5(4): 370- 383.

Chan, P., Tomlinson, B., Lee, C.B. and Lee, Y.S. 1996 Effectiveness and safety of low-dose pravastatin and squalene, alone and in combination, in elderly patients with hypercholesterolemia. Journal of Clinical Pharmacology; 36:422 - 7. 
Cortese, C., Levy, Y. and Janus, E. D. 1983. Modes of action of lipid-lowering diets in man: studies of apolipoprotein B kinetics in relation to fat consumption and dietary fatty acid composition. European Journal of Clinical Invest 13:79-85.

Folch, J., Lees, M. and Stanley, G. H. 1957. A simple method for the isolation and purification of total lipids from animal tissues. Journal of Biological Chemistry 226: 497- 509.

Fowomola, M.A. and Akindahunsi, A.A. 2007. Nutrients and Antinutrients of Hura crepitan seed. Journal of Medicinal Food, 10(1): 159-164.

Gaydou, E.M., J.P. Bianchini and J. Ratovogery, 1983. Triterpene alcohols, methyl sterols and fatty acids in five Malagasy legume seed oils. Journal of Agricultural and Food Chemistry, 31: 833-836.

Gidez, L., Miller, G. J., Burstein, M., Slagle, S. and Eder, H. A. 1982. Separation and quantization of subclass of human plasma high density lipoproteins by a simple precipitation procedure. Journal of lipid Research 23: 1206-1223

Grosso, N.R. and C.A. Guzman, 1995. Chemical composition of aboriginal peanut (Arachis hypogaea L.) seeds from Peru. Journal of Agricultural and Food Chemistry, 43: 102-105.

Grosso, N.R., E.I. Lucini, A.G. Lopez and C.A. Guzman, 1999. Chemical composition of aboriginal peanut (Arachis hypogaea L.) seeds from Uruguay. Grasasyaceites.revistas.csic.es 50: 203-207.

Grosso, N.R., J.A. Zygadlo, A.L. Lamarque, D.M. Maestri and C.A. Guzman, 1997. Proximate, fatty acid and sterol compositions of aboriginal peanut (Arachis hypogaea L.) seeds from Bolivia. Journal of the Science of Food and Agriculture, 73: 249-356.

Ighosotu, S. and Tonukari, I. N. J. 2010. The influence of dietary intake on the serum lipid profile, body mass index and risk of cardiovascular diseases in adults of the Niger Delta region. International Journal of Nutrition and Metabolism 2 (3): 40 - 44.

Jambunathan, R., R. Sridhar, K. Raghunath, S.L. Dwivedi and S.N. Nigam. 1993. Oil quality characteristics and headspace volatiles of newly released groundnut (Arachis hypogaea L.) cultivars. Journal of the Science of Food and Agriculture, 61: 23-30. 
Kennelly, P. J. and Rodwell, V. W. 1985. Regulation of 3-hydroxy-3-methylglutaryl coenzyme A reductase by reversible phosphorylation-dephosphorylation. Journal of Lipid Research 26: 903 914.

Keys, A., Menotti, A. and Karvonen, M. J. 1986. The diet and 15-year death in the seven countries study. America Journal Epidemiology; 124: 03- 15.

Liu, G. C. K., Ahrens, E. H. Jr., Schreibman, P. H., Samuel, P., McNamara, D. J. and Crouse, J. R. 1975. Measurement of cholesterol synthesis in man by isotope kinetics of squalene. Proceedings of the National Academic of Science USA; 72:4612-6.

Mensink, R. P. and Katan, M. B. 1992. Effect of dietary fatty acids on serum lipids and lipoproteins. A meta-analysis of 27 trials. Arteriosclerosis and Thrombosis. 12(8): 911 - 919.

Miettinen, T. A. and Vanhanen, H. 1994 Serum concentration and metabolism of cholesterol during rapeseed oil and squalene feeding. America Journal of Clinical Nutrition 59: 356-63.

Muhammed Nasiru Abdulkadir, Isiaka Adekunle Amoo, Adeniyi Olufemi Adesina 2013. Chemical composition of Hura crepitans seeds and antimicrobial activities of its oil. International Journal of Science and Research; 2319-7064

Murray, R. K., Granner, D. K., Mayes, P. A. and Rodwell, V. W. 2003. Harper's Illustrated Biochemistry. A Lange Medical Book. 26thEdition, McGraw Hill, Asia.

Oderinde, R.A., Ajayi, I.A. and Adewuyi, A. 2009. Characterization of seed and seed oil of Hura crepitans and The Kinetics of Degradation of the oil During Heating. Electronic journal of envirionmental, agriculture and food chemistry 8(3): 201-208.

Odoemelam, S. A. 2005. Proximate composition and selected physicochemical properties of the seeds of African oil bean (Pentaclethra marcrophylla). Pakistan Journal Nutrition, 4, 382 -383.

Okolie, P. N, Uciboi-Egbenni, P. O. and Ajekwene, A.E. 2012. Extraction and Quality Evaluation of Sandbox Tree Seed (Hura crepitan) Oil. World Journal of Agricultural Sciences 8 (4): 359-365.

Oluba, O. M., Eidangbe, G. O., Ojieh, G. C. and Idonije, B. O. 2011. Palm and egusi melon oils lower serum and liver lipid profile and improve antioxidant activity in rats fed a high fat diet. International Journal of Medicine and Medical Sciences 3(2): 47 - 51. 
Ong, A.S.H., Y.M. Choo and C.K. Ooi, 1995. Developments in Palm Oil. In: Developments in Oils and Fats, Hamilton, R.J. (Ed.). Blackie Academic and Professional Glasgow, UK., pp: 153191.

Oyeleke, G.O., Olayiwola, O.A. and Latona, D.F. 2012. Chemical Examination Of Sandbox (Hura Crepitans) Seed: Proximate, Elemental And Fatty Acid Profile. IOSR Journal of Applied Chemistry 1 (2): 10-13.

Rao, A. and Ramakrishnan, A. 1975. Indirect assessment of hydroxymethylglutaryl-CoA reductase (NADPH) activity in liver tissue.. Clinical Chemistry 21: 1523.

Romon, M., Nuttens, M., Theret, N., Delbart, C., Lecerf, J., Fruchart, J. and Salomes, J. 1995. Comparison between fat intake assessed by a 3-day food record and phospholipid fatty acid composition of red blood cells: Results from the monitoring of cardiovascular disease - Lillie Study. Metabolism, 44(9): 1139 - 1145.

Rose, H. G. and Oklander, M. 1965. Improved procedure for the extraction of lipids from human erythrocytes. Journal of Lipid Research 6: 428-431.

Sanossian, N., Jeffrey, L. S., Mohamad, N. and Bruce, O. 2007. High-Density Lipoprotein Cholesterol, an emerging target for stroke treatment. Stroke. 38: 1104-1109.

Sawada, H., Takami, K. and Asahi, S. 2005. A toxicogenic approach to drug-induced phospholipidosis: analysis of its induction mechanism and establishment of a novel screening system. Toxicology Science, 83: 282 - 292.

Shepherd, J., Packard, C. J. and Grundy, S. M. 1980. Effects of saturated and polyunsaturated fat diets on the chemical composition and metabolism of low density lipoproteins in man. Journal of Lipid Research 21: 1-9.

Stewart, J. C. M. 1979. Colorimetric determination of phospholipids with ammonium ferrothiocyanate. Analytical Biochemistry 104: 10-14.

Storm, H. M, Oh, S. Y, Kimler, B. F. and Norton S. 1993 Radioprotection of mice by dietary squalene. Lipids 28:555-9.

Strandberg, T. E, Tilvis, R. S. and Miettinen, T. A. 1990. Metabolic variables of cholesterol during squalene feeding in humans: comparison with cholestyramine treatment. Journal of Lipid Research $31: 1637-43$ 
Tilvis, R. S. and Miettinen, T. A. 1983. Dietary squalene increases tissue sterols and fecal bile acids in the rat. Lipids18: 32-6.

Turner, J. D., Le, N. A. and Brown, W. V. 1981. Effect of changing dietary fat saturation on lowdensity lipoprotein metabolism in man. America Journal of Physiology 241:E57-E63.

Ugbaja, R. N., Afolabi, O. K., Onunkwor, O. B, Akinloye, D. I., Ayanda, T. M, Oladejo, O. A, Sofowora, A. O, Falana, T. M and Ajayi, M. O. 2015. Lipidomics of blood and organs of rats fed diets supplemented with different edible oil. Animal research international 12(2); 2189-2202

World Health Organization. 1993. Fats, oils and related product. Food standard program.Codex Alimentarius Commission.Food and Agriculture Organization of the United Nations. World Health Organization, Rome. 8: 33-35pp 